\title{
Themoanaerobacterium calidifontis sp. nov., a novel anaerobic, thermophilic, ethanol-producing bacterium from hot springs in China
}

\author{
Shu-mei Shang $\cdot$ Long Qian $\cdot$ Xu Zhang $\cdot$ Kun-zhi Li $\cdot$ \\ Irbis Chagan
}

Received: 29 December 2012 / Revised: 15 April 2013 / Accepted: 19 April 2013 / Published online: 10 May 2013

(C) The Author(s) 2013. This article is published with open access at Springerlink.com

\begin{abstract}
A novel thermophilic Gram staining positive strain Rx1 was isolated from hot springs in Baoshan of Yunnan Province, China. The strain was characterized as a hemicellulose-decomposing obligate anaerobe bacterium that is rod-shaped (diameter: $0.5-0.7 \mu \mathrm{m}$; length: $2.0-6.7 \mu \mathrm{m}$ ), spore-forming, and motile. Its growth temperature range is $38-68{ }^{\circ} \mathrm{C}$ (optimum $50-55{ }^{\circ} \mathrm{C}$ ) and $\mathrm{pH}$ range is $4.5-8.0$ (optimum 7.0). The maximum tolerance concentration of $\mathrm{NaCl}$ was $3 \%$. Rx1 converted thiosulfate to elemental sulfur and reduced sulfite to hydrogen sulfide. The bacterium grew by utilizing xylan and starch, as well as a wide range of monosaccharide and polysaccharides, including glucose and xylose. The main products of fermentation were ethanol, lactate, acetate, $\mathrm{CO}_{2}$, and $\mathrm{H}_{2}$. The maximum xylanase activity in the culture supernatant after $30 \mathrm{~h}$ of incubation at $55^{\circ} \mathrm{C}$
\end{abstract}

Communicated by Harald Huber.

The GenBank/EMBL/DDBJ accession number for the 16S rRNA gene sequence of strain $\mathrm{Rx} 1$ is AB544080.

Electronic supplementary material The online version of this article (doi:10.1007/s00203-013-0895-5) contains supplementary material, which is available to authorized users.

S. Shang

Faculty of Environmental Science and Engineering, Kunming

University of Science and Technology, Chenggong Campus,

Kunming 650500, China

e-mail: shangsm@163.com

S. Shang $\cdot$ L. Qian $\cdot$ X. Zhang $\cdot$ K. Li $\cdot$ I. Chagan $(\varangle)$ Faculty of Life Science and Biotechnology, Kunming University of Science and Technology, Chenggong Campus, Kunming 650500, China

e-mail: irbisc@gmail.com was $16.2 \mathrm{U} / \mathrm{ml}$. Rx1 DNA G $+\mathrm{C}$ content was $36 \mathrm{~mol} \%$. 16S rRNA gene sequence analysis indicated that strain Rx1 belonged to the genus Thermoanaerobacterium of the family 'Thermoanaerobacteriaceae' (Firmicutes), with Thermoanaerobacterium aciditolerans 761-119 (99.2 \% 16S rRNA gene sequence similarity) being its closest relative. DNADNA hybridization between Rx1 and T. aciditolerans 761119 showed $36 \%$ relatedness. Based on its physiological and biochemical tests and DNA-DNA hybridization analyses, the isolate is considered to represent a novel species in the genus Thermoanaerobacterium, for which the name Thermoanaerobacterium calidifontis sp. nov. is proposed, with the type strain is Rx1 (=JCM $18270=$ CCTCC M 2011109).

Keywords Themoanaerobacterium calidifontis sp. nov. Hot springs · Thermophilic · Phylogeny

\section{Introduction}

The biotechnological potential and evolutionary significance of thermophiles has led to intensive research focused on anaerobic, saccharolytic, and thermophilic bacteria, which are members of the genera Thermoanaerobacter, Thermoanaerobacterium, and Clostridium (Xue et al. 2001). Within the genus Thermoanaerobacterium, eight species have been isolated, and more recently the taxonomic relationships between some of these species have been better defined (Romano et al. 2010). Most studies of eubacterial thermophilic anaerobes have focused on the saccharolytic bacteria, which form ethanol and lactate and are promising tools for creating alternative fuels from plant biomass (Shaw et al. 2008; Patel et al. 2006). Moreover, their ethanol production capacity involving utilization of glucose and the other hexose transformed from cellulose materials has 
been the major focus of those studies. Since only a few of the natural anaerobic thermophilic microorganisms identified to date are capable of efficiently fermenting xylose and the other pentose transformed from hemicellulose materials, we aimed to isolate novel thermophilic anaerobic hemicellulose-decomposing bacteria from hot springs sample.

The Baoshan region is situated in the southwest of Yunnan Province and encompasses a large number of natural hot springs. Water and sediment samples were collected from the region's hot springs and measured temperature $\left(50-70{ }^{\circ} \mathrm{C}\right)$ and $\mathrm{pH}(6.0-7.5)$. Using oat spelt xylan as substrate, we isolated a Gram staining positive, obligately anaerobic, thermophilic bacterium (strain Rx1).

In this paper, we describe the isolation and characterization of the ethanol-producing strain Rx1. The physiological, biochemical, and phenotypic features of Rx1 were determined, and the results of DNA-DNA relatedness studies indicated that Rx1 is a new member of the genus Thermoanaerobacterium. The name Themoanaerobacterium calidifontis is proposed.

\section{Materials and methods}

\section{Strains and culture conditions}

Thermoanaerobacterium aciditolerans DSM $16487^{\mathrm{T}}$ and Thermoanaerobacterium saccharolyticum $\mathrm{DSM} 7060^{\mathrm{T}}$ were purchased from the Deutsche Sammlung von Mikroorganismen und Zellkulturen (DSMZ; Braunschweig, Germany) and were cultured in modified medium 640 at $55^{\circ} \mathrm{C}$.

All culturing of Rx1 was performed in modified DSMZ medium 640, containing (per liter distilled water) $0.9 \mathrm{~g}$ $\mathrm{NH}_{4} \mathrm{Cl}, 0.9 \mathrm{~g} \mathrm{NaCl}, 0.4 \mathrm{~g} \mathrm{MgCl}_{2} \times 6 \mathrm{H}_{2} \mathrm{O}, 0.75 \mathrm{~g} \mathrm{KH}_{2} \mathrm{PO}_{4}$, $1.5 \mathrm{~g} \mathrm{~K}_{2} \mathrm{HPO}_{4}, 2.5 \mathrm{mg} \mathrm{FeCl} 3 \times 6 \mathrm{H}_{2} \mathrm{O}, 0.75 \mathrm{~g}$ cysteine$\mathrm{HCl} \times \mathrm{H}_{2} \mathrm{O}, 2 \mathrm{~g}$ tryptone, $1 \mathrm{~g}$ yeast extract, $1 \mathrm{ml}$ trace element solution SL-10 (see medium 320, DSMZ), $0.5 \mathrm{mg}$ resazurin, $5 \mathrm{ml}$ vitamin solution (see medium 141, DSMZ, filter-sterilized), $10.0 \mathrm{~g}$ substrate. After adjusting $\mathrm{pH}$ to 7.0, the medium was prepared anaerobically under $100 \%$ $\mathrm{N}_{2}$ and dispensed $5 \mathrm{ml}$ portions into $15 \mathrm{ml}$ Hungate tubes. Finally, the medium solutions were autoclaved.

Initial enrichment was carried out at $60{ }^{\circ} \mathrm{C}$ by inoculating the samples of mixed sediment and water into $250 \mathrm{ml}$ anaerobic reagent bottles (50 $\mathrm{ml}$ modified medium 640). Oat spelt xylan was added as substrate, and the culture incubated until visible growth was observed. The ethanol-producing cultures were isolated through several serial liquid dilutions and applied to the anaerobic phytagel $(1.2 \%$, w/v) shake-roll tube technique (Ljungdahl and Wiegel 1986) with xylose as substrate. Pure strains were stored as liquid cultures under anaerobic conditions at 4 and $-80{ }^{\circ} \mathrm{C}$. One of the isolated strains was strain Rx1 for further characterization.
Morphological, physiological, and biochemical analysis

Gram reaction was determined using a Gram staining kit (Guangdong Huankai Microbial Sci. \& Tech Co., Ltd. Guangdong, China). Cell morphology was examined by phase-contrast microscopy (Leica, Germany). Bacteria tolerance of $\mathrm{NaCl}(0-5 \%$, w/v), temperature (from 35 to $70{ }^{\circ} \mathrm{C}$ ), $\mathrm{pH}$ (from 3.5 to 8.5 ), and substrates (complete list in Table 1) was determined by growing on the modified 640 medium for four days and measuring the optical density (OD) at $600 \mathrm{~nm}$ using a 4802 UV/VIS double-beam spectrophotometer (Unico, Dayton, NJ, USA). Metabolite products were measured by high-performance liquid chromatography (HPLC) and gas chromatography (GC-SC2), as previously described (Shaw et al. 2008; Romano et al. 2010; Ren et al. 2008). Ethanol tolerance was determined by supplementing the modified 640 medium with ethanol (from 0 to $5.0 \%, \mathrm{v} / \mathrm{v}$ ) after autoclaving. The ability of Rx1 to convert thiosulfate, sulfate, sulfite, and elemental sulfur was assessed by adding thiosulfate $(7 \mathrm{~g} / \mathrm{l})$, sulfate $(2 \mathrm{~g} / \mathrm{l})$, sulfite $(0.76 \mathrm{~g} / \mathrm{l})$, or elemental sulfur $(2 \mathrm{~g} / \mathrm{l})$, respectively, to the modified medium 640 (Kublanov et al. 2007; Liu et al. 1996). All the tests were performed in triplicate. Phase-contrast microscopy was used to visualize the sulfur globules formation (Lee et al. 2007). The gas from the headspace $(10 \mathrm{ml})$ culture of $\mathrm{Rx} 1$ was transferred via sterile syringe into a test tube containing $5 \mathrm{ml}$ of $50 \mathrm{~g} / \mathrm{l}$ copper sulfate solution, and the formation a black precipitate of copper sulfide was observed. At the same time, one control sample was used without gas injected in the test tube, and another control sample was used with gas injected from the headspace of Rx1 cultures, but without added sulfate, sulfite, or elemental sulfur in the modified medium 640.

\section{Enzymatic hydrolysis}

A $500 \mathrm{ml}$ anaerobic reagent bottle containing $250 \mathrm{ml}$ of modified 640 medium was inoculated with $2.5 \mathrm{ml}$ of an overnight culture of Rx1 in the exponential growth phase. Fermentation was carried out at $55^{\circ} \mathrm{C}$ with $10 \mathrm{~g} / \mathrm{l}$ of oat spelt xylan as substrate. Aliquots of the fermentation liquid were collected at different time points and were centrifuged $(12,000 \mathrm{rpm}, 5 \mathrm{~min})$ to remove cells. The supernatant (enzyme solution) was then analyzed as described below.

Xylanase activity was determined in triplicate reactions using the dinitrosalicylic acid (DNS) method (Bailey et al. 1992). The initial reaction mixture consisted of $0.5 \mathrm{ml}$ of $1 \mathrm{mM}$ oat spelt xylan in water and $0.5 \mathrm{ml}$ of enzyme solution. After incubation at $55{ }^{\circ} \mathrm{C}$ for $10 \mathrm{~min}$, the DNS reagent was added, and the mixture was boiled at $100{ }^{\circ} \mathrm{C}$ for 5 min. After cooling, water was added to bring the volume to $20 \mathrm{ml}$, and the amount of reduced sugar released from the xylan substrate was measured as $\mathrm{OD}_{540}$. The control 
Table 1 Phenotypic characteristics that differentiate strain Rx1 from the other recognized species of the genus Thermoanaerobacterium

\begin{tabular}{|c|c|c|c|c|}
\hline Characteristic & 1 & 2 & 3 & 4 \\
\hline Spore formation & + & + & + & - \\
\hline Flagellation & & Single flagellum & Peritrichous & Peritrichous \\
\hline $\begin{array}{l}\text { Temp range/ } \\
\text { optimum temp }\left({ }^{\circ} \mathrm{C}\right)\end{array}$ & $38-68 / 50-55$ & $37-68 / 55$ & $35-66 / 60-63$ & $45-70 / 60$ \\
\hline $\mathrm{pH}$ range/optimum $\mathrm{pH}$ & $4.5-8.0 / 7.0$ & $3.2-7.1 / 5.7$ & $3.8-6.8 / 5.2$ & $5.0-7.5 / 6.0$ \\
\hline $\begin{array}{l}\mathrm{NaCl} \text { range for } \\
\text { growth }(\%, \mathrm{w} / \mathrm{v})\end{array}$ & $0-3 \%$ & $0-3 \%$ & ND & ND \\
\hline $\begin{array}{l}\text { DNA G }+\mathrm{C} \text { content } \\
(\mathrm{mol} \%)\end{array}$ & 36 & $34 \pm 0.5$ & $34.5-35$ & 36 \\
\hline Cell size $(\mu \mathrm{m})$ & $0.5-0.7 \times 2.0-6.7$ & $0.4 \times 3.0-12.0$ & $0.7-1.0 \times 2.1-14.3$ & $0.8-1.0 \times 3.0-15.0$ \\
\hline \multicolumn{5}{|l|}{ Utilization of } \\
\hline Arabinose & + & + & + & ND \\
\hline D-galactose & + & + & ND & + \\
\hline $\mathrm{D}(+)$-cellobiose & + & $+^{*}$ & ND & + \\
\hline Lactose & + & + & + & + \\
\hline Cellulose & - & $-*$ & ND & - \\
\hline Xylan from oat spelt & + & + & + & + \\
\hline Pectin & + & $+^{*}$ & + & ND \\
\hline Xylitol & - & $-*$ & ND & ND \\
\hline Pyruvate & + & - & - & ND \\
\hline Ethanol & - & - & - & ND \\
\hline Ribose & ND & + & + & - \\
\hline Sorbitol & - & + & ND & - \\
\hline Glycerol & - & - & - & ND \\
\hline Sucrose & - & + & ND & + \\
\hline \multicolumn{5}{|l|}{ Reduction of } \\
\hline$S^{0}$ & - & - & - & ND \\
\hline Thiosulfate & $+\left(S^{0}\right)$ & $+\left(S^{0}\right)$ & $+\left(S^{0}\right)$ & $+\left(S^{0}\right)$ \\
\hline Sulfite & $+\mathrm{H}_{2} \mathrm{~S}$ & $+\mathrm{H}_{2} \mathrm{~S}$ & ND & ND \\
\hline Sulfate & - & - & - & ND \\
\hline
\end{tabular}

Strains: 1 Rx1, 2 T. aciditolerans DSM $16487^{\mathrm{T}}, 3$ T. aotearoense DSM10170 ${ }^{\mathrm{T}}, 4$ T. saccharolyticum DSM 7060 . Data for Rx1 are from this study; strain 2 is from (Kublanov et al. 2007) and this study; strain 3 is from (Liu et al. 1996; Kublanov et al. 2007); strain 4 is from (Lee et al. 1993; Kublanov et al. 2007). All species utilize glucose, D-xylose, D-mannose*, mannitol, D-fructose*, maltose, and starch soluble, and produce ethanol, acetate, lactate, $\mathrm{H}_{2}$, and $\mathrm{CO}_{2}$ to form glucose. + , positive; -, negative; $N D$ no data available

* Data are from this study

reaction lacked the enzyme solution. Measurements of a series of xylose dilutions were used as standards to calculate the quantity of reduced sugar. One unit of xylanase activity was defined as the activity that released $1 \mu \mathrm{mol}$ of xylose in 1 min under the assay conditions.

Polyacrylamide gel electrophoresis (PAGE) of soluble proteins

SDS-PAGE of whole cell protein extracts is used widely in bacterial taxonomy and is suitable for grouping strains at the species level (Bandyopadhyay et al. 2013; Dicks et al. 1990). For total soluble cell protein analysis, $10 \mathrm{ml}$ aliquots of late exponential phase cultures grown at $55{ }^{\circ} \mathrm{C}$ in the modified medium ( $\mathrm{pH}$ 6.5) containing $1.0 \%$ glucose as the substrate was harvested by centrifugation. The total cellular protein was extracted as described previously (Liu et al. 1996), and the protein concentration was determined by the Bradford method (Bradford 1976). Samples containing $50 \mu \mathrm{g}$ of protein from each strain were analyzed by SDSPAGE, as previously described (Laemmli 1970).

16S rRNA gene sequencing and phylogenetic analysis

Bacterial 16S rRNA was amplified by PCR using the previously described conditions (Rivas et al. 2009) and the following universal primers: reverse 1541R, 5'-TGYG GNTGGATCACCTCCTT-3' (Escherichia coli positions 
1,509-1,522) and forward 8F, 5'-AGAGTTTGATCTG GCTCAG-3' (E. coli positions 8-27). Sequence comparison of the 16S rRNA gene was carried out using the BLAST program (http://www.ncbi.nlm.nih.gov/blast) and the global alignment algorithm of the EzTaxon server (htt p://www.eztaxon.org/; Chun et al. 2007). After multiple sequence alignment by ClustalX (Thompson et al. 1997), a phylogenetic tree was constructed by the neighbor-joining and minimum evolution methods using Molecular Evolutionary Genetics Analysis (MEGA) software, version 5.0 (Tamura et al. 2011) and evaluated by bootstrap resampling with 1,000 replicates.

\section{Determination of G $+\mathrm{C}$ and DNA-DNA hybridization}

Genomic DNA was extracted, and $\mathrm{G}+\mathrm{C}$ content was evaluated in triplicate samples by HPLC using the method described by Murray and Thompson (1980). Briefly, purified DNA samples were mixed with $45 \%$ perchloric acid (DNA: $45 \%$ perchloric acid $=10 \mu \mathrm{g}: 1 \mu \mathrm{l}$ ) and boiled at $98{ }^{\circ} \mathrm{C}$ for $2 \mathrm{~h}$. Supernatants were harvested by centrifugation $\left(5,000 \mathrm{~g}, 10 \mathrm{~min}, 4{ }^{\circ} \mathrm{C}\right)$ and diluted 50-fold using distilled water for HPLC analysis (Mesbah et al. 1989).

The DNA-DNA hybridization technique has been especially successful in resolving taxonomic relationships among closely related organisms (at the species level and below) (Lee et al. 1993), Here, this technique was carried out according to the spectrophotometric method (Ley et al. 1970; Huss et al. 1983; Jahnke 1992), using a UV-1700 spectrophotometer (Shimadzu, Kyoto, Japan) equipped with a DCW-2008 thermo bath (Yuan et al. 2008). G + C content and DNA-DNA hybridization assays were performed in triplicate.

\section{Results}

Isolation and characterization of a novel anaerobic, thermophilic, hemicellulose-decomposing bacteria

An anaerobic, thermophilic, ethanol-producing strain ( $\mathrm{Rx} 1)$ was obtained from samples of mixed sediment and water of hot springs. Colonies of Rx1 grown within the phytagel shake-roll tubes appeared as white, circular, $0.5-1 \mathrm{~mm}$ in diameter, and slightly convex (colonies were adhered to the inner surface of the phytagel shake-roll tubes). Analysis of the single cells indicated that the strain was Gram staining positive, motile, rod-shaped, $0.5-0.7 \mu \mathrm{m}$ in diameter, and 2.0-6.7 $\mu \mathrm{m}$ in length (Table 1). The average (mean of $n=15$ ) length of the individual organisms was longer in the stationary phase than in the exponential growth phase. The formation of terminal spores was observed during the late exponential and early stationary phase (Fig. 1).

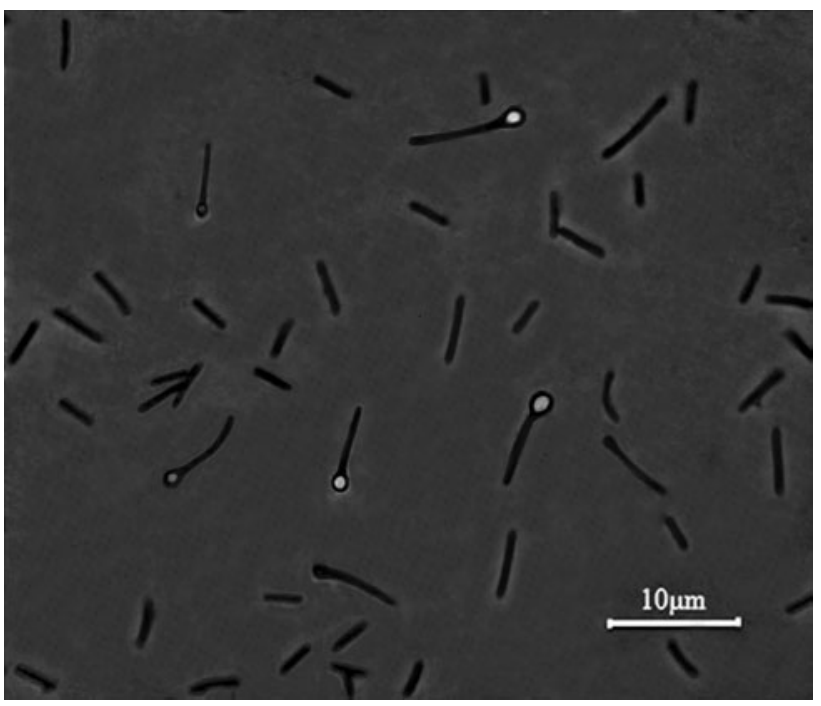

Fig. 1 Cell morphology of strain $T$. calidifontis Rx1 grown in modified 640 medium with $1 \%$ xylose as substrate. Phase-contrast micrograph of late exponential growth cells and spores shows the formation of terminal spores. Bar $10 \mu \mathrm{m}$

Approximately $6.0 \%$ of the cells sporulated in liquid media, and the spores were oval, $1.5-1.7 \mu \mathrm{m}$ in length and $1.0-1.5 \mu \mathrm{m}$ in diameter. The length of the end of the mother cells ranged between 5.9 and $7.6 \mu \mathrm{m}$, so that they were longer than normal cells. The strain did not grow in oxidized medium, as evidenced by the pink color of resazurin. The strain had a temperature growth range from $38{ }^{\circ} \mathrm{C}$ to $68{ }^{\circ} \mathrm{C}$, with the optimal temperature being between 50 and $55^{\circ} \mathrm{C}$. For up to $96 \mathrm{~h}$, no growth was observed at temperatures $\leq 37{ }^{\circ} \mathrm{C}$ or $\geq 70{ }^{\circ} \mathrm{C}$. The $\mathrm{pH}$ range for growth at $55^{\circ} \mathrm{C}$ was between $\mathrm{pH} 4.5$ and 8.0, with the optimum $\mathrm{pH}$ being 7.0. For up to $96 \mathrm{~h}$, no growth was observed at $\mathrm{pH} \leq 4.3$ or $\geq 8.2$. The growth curve of Rx1 under optimal growth condition with $5 \mathrm{~g} / \mathrm{l}$ xylose substrate is shown in Fig. 3; the doubling time under the optimal growth condition was approximately $50 \mathrm{~min}$. Growth of $\mathrm{Rx} 1$ occurred at $\mathrm{NaCl}$ concentrations ranging from 0 to $3 \%$, but no growth was observed in $4 \% \mathrm{NaCl}$.

$\mathrm{Rx} 1$ was able to grow in the presence of the following polysaccharide substrates: xylan, starch, and pectin. It also was able to utilize various monosaccharides and disaccharides, including glucose, xylose, fructose, mannose, mannitol, galactose, maltose, lactose, cellobiose, arabinose, and pyruvate (filter-sterilized). However, no growth was observed in the presence of sucrose, xylitol, sorbitol, cellulose, glycerol, or ethanol (Table 1). The fermentation products from xylan, starch, cellobiose, xylose, and glucose substrates were mainly ethanol, acetate, lactate, $\mathrm{CO}_{2}$, and $\mathrm{H}_{2}$ (production of $\mathrm{H}_{2}$ and $\mathrm{CO}_{2}$ was detected by gas chromatography), respectively. Under optimal conditions, when Rx1 was grown on $5 \mathrm{~g} / 1$ of glucose for $48 \mathrm{~h}$, 
the fermentation products were ethanol $(29.3 \mathrm{mM})$, acetate $(13.1 \mathrm{mM})$, lactate $(16.2 \mathrm{mM}), \mathrm{H}_{2}(38.1 \mathrm{mM})$, and $\mathrm{CO}_{2}$ $(8.6 \mathrm{mM})$. Ethanol yield reached $58 \%$ of the theoretical yield (we assumed that all of consumed glucose/xylose was converted into ethanol). In optimal conditions, when $\mathrm{Rx} 1$ was grown on $5 \mathrm{~g} / \mathrm{l}$ of xylose for $48 \mathrm{~h}$, the amounts of ethanol, acetate, lactate, $\mathrm{H}_{2}$ and $\mathrm{CO}_{2}$ were $45.1,1.3,10.5$, 29.7 , and $8.8 \mathrm{mM}$, respectively. Ethanol yield reached $81 \%$ of the theoretical yield. When Rx1 was grown on $5 \mathrm{~g} / \mathrm{l}$ of xylan for $48 \mathrm{~h}$, the amounts of ethanol, acetate, and lactate were $25.2,0.8$, and $7.3 \mathrm{mM}$, respectively. These results indicated that $\mathrm{Rx} 1$ was able to produce ethanol from the majority of hexose and pentose, even polysaccharides; the ethanol yields were 1.0-4.3 and 2.2-34.7 times those of lactate and acetate, respectively. However, ethanol yields of most of the known Thermoanaerobacterium species were lower or equal to those for lactate and acetate (Romano et al. 2010; Kublanov et al. 2007; Liu et al. 1996). Therefore, $\mathrm{Rx} 1$ is considered as potentially useful strains for converting biomass to produce ethanol.

$\mathrm{Rx} 1$ was able to grow in the presence of $3 \%(\mathrm{v} / \mathrm{v})$ ethanol. Moreover, addition of thiosulfate $(7 \mathrm{~g} / \mathrm{l})$ to the modified 640 medium significantly stimulated growth of Rx1. $\mathrm{Rx} 1$ was found to convert thiosulfate to sulfur globules $\left(\mathrm{S}^{0}\right)$, which were detected both inside the cells and in the medium (Fig. 2), but the ethanol yield of Rx1 decreased under this condition by $22 \%$. Rx1 also grew well in the presence of sulfate, elemental sulfur and sulfite, and sulfite was reduced to hydrogen sulfide, but neither sulfate nor elemental sulfur was reduced (Fig. S1); however, the bacterial growth and ethanol production capability were not remarkably influenced by these medium conditions (Fig. 3).

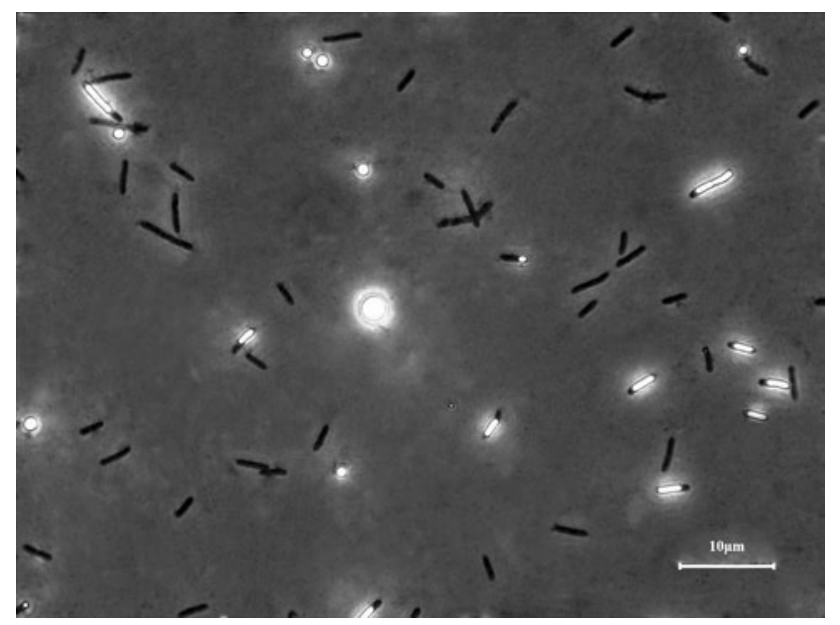

Fig. 2 Thermoanaerobacterium calidifontis $\mathrm{Rx} 1$ grown in modified 640 medium containing $1 \%$ xylose and $7 \mathrm{~g} / \mathrm{l} \mathrm{Na} \mathrm{S}_{2} \mathrm{O}_{3}$ at $55^{\circ} \mathrm{C}$. The cells of strain Rx1 are shown during the late exponential or early stationary phase. Note that the phase-bright sulfur globules accumulated in the medium and in the cells. Bar $10 \mu \mathrm{m}$

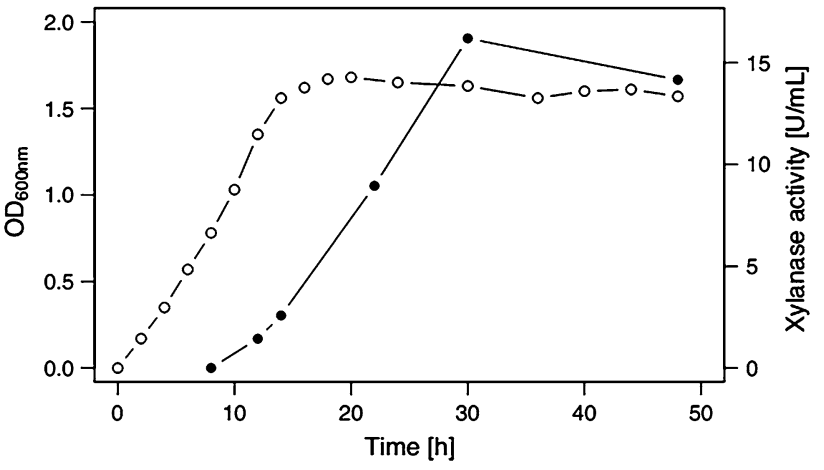

Fig. 3 Growth curve and xylanase activities of supernatants from $\mathrm{Rx} 1$ cultures grown at $55^{\circ} \mathrm{C}$. Filled circles xylanase activities, Rx 1 grown in $1 \%$ xylan. Open circles growth curve, Rx 1 grown in $1 \%$ xylose

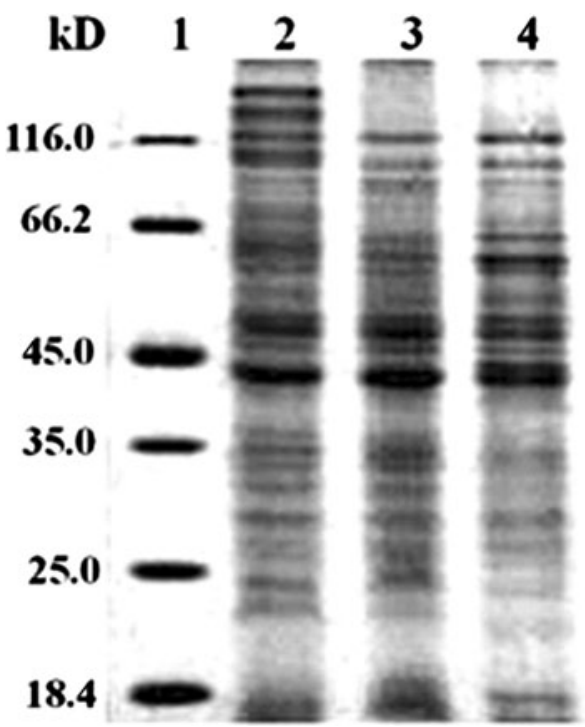

Fig. 4 Electrophoretic comparison of cellular proteins from different strains. Lane 1 marker; lane $2 \mathrm{Rx} 1$; lane 3, Thermoanaerobacterium aciditolerans (DSM $\left.16487^{\mathrm{T}}\right)$; lane 4, Thermoanaerobacterium saccharolyticum (DSM 7060 ${ }^{\mathrm{T}}$ )

Rx1 grew on xylan, and xylanase activities were detected in culture supernatants after $8 \mathrm{~h}$. The highest enzyme activity was $16.2 \mathrm{U} / \mathrm{ml}$ after culture for $30 \mathrm{~h}$ at $55^{\circ} \mathrm{C}$ (Fig. 3). Xylanase activity in culture supernatants were compared with those detected from T. thermosulfurigenes $(0.023 \mathrm{U} / \mathrm{ml})$, T. xylanolyticum $(0.067 \mathrm{U} / \mathrm{ml})$, and $T$. saccharolyticum $(0.108 \mathrm{U} / \mathrm{ml})$ strains of the Thermoanaerobacterium genus, and found to be up to 703, 241 and 150 times higher (Lee et al. 1993). Xylanase may be a thermostable enzyme, giving it potential in applications for the ethanol-producing industry. The properties, production, and applications of xylanase need to be further researched. 
Fig. 5 Phylogenetic tree based on 16S rRNA gene sequences, showing the position of isolate T. calidifontis $\mathrm{Rx} 1$ in the genus Thermoanaerobacterium. The tree was constructed by neighbor-joining method with 1,000 replicates of bootstrapping. GenBank accession numbers are given in parentheses. Bootstraps are the confidence values (expressed as percentages) obtained from 1,000 replications. Bar 5 nucleotide substitutions per 100 nucleotides

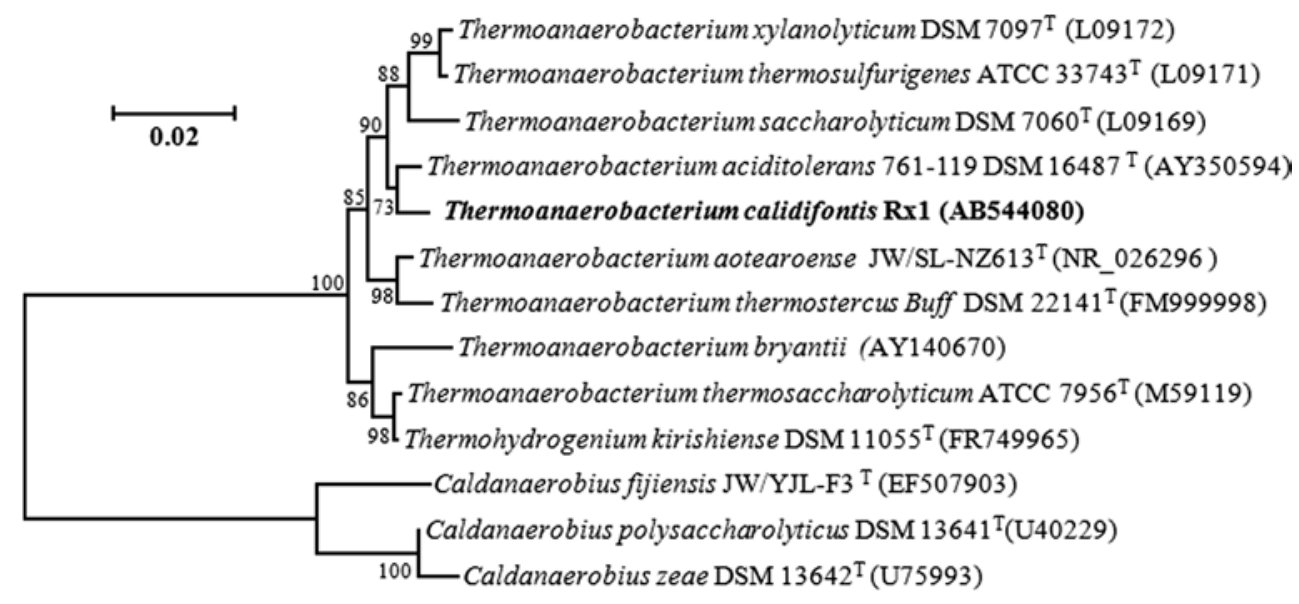

Protein profile

Strain Rx1 showed distinct protein pattern from those of its closest related reference strains (Fig. 4), indicating that strain Rx1 is different from the other two species of the Thermoanaerobacterium genera and supporting its identification as a novel species.

Phylogenetic relationships

BLAST search of the 1,473 nucleotide sequence of the Rx 1 $16 \mathrm{~S}$ rRNA gene revealed that this novel strain was a member of genus Thermoanaerobacterium of the family Thermoanaerobacteriaceae, which belongs to the order Thermoanaerobacteriales of the class Clostridia in the phylum Firmicutes (Garrity et al. 2003). Rx1 showed the highest identity with $T$. aciditolerans $761-119^{\mathrm{T}}(99.2 \%)$ (Kublanov et al. 2007). The phylogenetic tree indicated that stain $\mathrm{Rx} 1$ was a member of the genus Thermoanaerobacterium (Fig. 5). Similar tree topologies were also found by the tree maximum evolution method (data not shown). DNA-DNA hybridization between strain Rx1 and T. aciditolerans 761$119^{\mathrm{T}}$ showed relatedness of only $36 \%$. The DNA G $+\mathrm{C}$ content of strain Rx1 was 36 mol \%, which was higher than that of T. aciditolerans $761-119^{\mathrm{T}}(34 \pm 0.5 \mathrm{~mol} \%)$.

\section{Discussion}

In this paper, we describe a new thermophilic anaerobic bacteria strain, Rx1, which was isolated from hot springs in Baoshan of Yunnan Province, China. Strain Rx1 showed the most sequence similarity $(99.2 \%)$ with $T$. aciditolerans. However, despite several phenotypic similarities, strain Rx1 differs from $T$. aciditolerans. As reported in Table 1, the $\mathrm{pH}$ range of $\mathrm{Rx} 1$ (4.5-8.0) was different from that of both T. aciditolerans (Kublanov et al. 2007) and
T. aotearoense (Liu et al. 1996) (3.2-7.1 and 3.8-6.8, respectively). The optimum $\mathrm{pH}$ of $\mathrm{Rx} 1$ (7.0) was also higher than T. aciditolerans (5.7) and T. aotearoense (5.2). Rx1 could utilize pyruvate, but not sorbitol or sucrose, the opposite of T. aciditolerans. In addition, Rx1 has a high yield xylanase and was able to ferment a series of carbohydrates, which suggests that it may be applied in the ethanol production process.

On the basis of the above distinctive physiological and biochemical properties, $\mathrm{G}+\mathrm{C}$ content and DNA-DNA hybridization values, the isolate $\mathrm{Rx} 1$ appears to represent a new species of the genus Thermoanaerobacterium. As such, the name Thermoanaerobacterium calidifontis sp. nov., is proposed.

\section{Description of Thermoanaerobacterium calidifontis sp.} nov.

Thermoanaerobacterium calidifontis: ca.li.di.fon'tis. L. adj. calidus, hot; L. n. fons fontis, spring, fountain; N.L. gen. n. calidifontis, of a hot spring.

Cells are Gram staining positive, rod-shaped, motile, an average diameter of $0.5-0.7 \mu \mathrm{m}$ and length of $2.0-6.7 \mu \mathrm{m}$, obligate anaerobe, hemicellulose-decomposing bacteria. Colonies are circular, $0.5-1 \mathrm{~mm}$ in diameter, white, and slightly convex. Oval terminal spores were formed in the late exponential to early stationary phases of growth, and the spores were oval, $1.5-1.7 \mu \mathrm{m}$ in length and $1.0-1.5 \mu \mathrm{m}$ in diameter. The organism is a moderate thermophile that grows between 38 and $68{ }^{\circ} \mathrm{C}$ (no growth at $\leq 37{ }^{\circ} \mathrm{C}$ or $\geq 70{ }^{\circ} \mathrm{C}$ ), with the optimum temperature between 50 and $55^{\circ} \mathrm{C}$, at $\mathrm{pH}$ between 4.5 and 8.0 (no growth at $\mathrm{pH} \leq 4.3$ or $\geq 8.2$ ), with the optimum $\mathrm{pH}$ of 7.0 , and low salinity $(\mathrm{NaCl}$ range $0-3 \%$ ). The bacteria grow by fermentation of xylan, starch, pectin, mannitol, glucose, xylose, fructose, galactose, maltose, lactose, cellobiose, mannose, arabinose, and pyruvate. Fermentation end products are ethanol, lactate, acetate, $\mathrm{H}_{2}$, and $\mathrm{CO}_{2}$. 
Under optimal growth conditions, the Rx1 strain fermented xylose and glucose for $48 \mathrm{~h}$ and produced ethanol yields that were 81 and $58 \%$ of the theoretical yields, respectively. The bacteria did not utilize sucrose, xylitol, sorbitol, cellulose, glycerol, or ethanol. The bacteria were able to convert thiosulfate to elemental sulfur, which accumulated both in the cells and in the culture medium. Sulfite was reduced to hydrogen sulfide. The genomic DNA G $+\mathrm{C}$ content (measured by HPLC) of strain Rx1 was $36 \mathrm{~mol} \%$. The type strain Rx1 (= JCM 18270 = CCTCC M 2011109) was isolated from a hot spring in Baoshan, Yunnan Province, China.

Acknowledgments The authors are very grateful to Dr. Jean Euzéby for helping with the new strain's nomenclature and Dr. Wenjun Li and Lingling Yang for providing use of experimental instrumentation and for their assistance in some of the laboratory procedures. The Natural Science Foundation of Yunnan Province (Project No. 2009CD038) provided funding for this study.

Open Access This article is distributed under the terms of the Creative Commons Attribution License which permits any use, distribution, and reproduction in any medium, provided the original author(s) and the source are credited.

\section{References}

Bailey MJ, Biely P, Poutanen K (1992) Interlaboratory testing of methods for assay of xylanase activity. J Biotechnol 23:257-270

Bandyopadhyay S, Schumann P, Das SK (2013) Pannonibacter indica sp. nov., a highly arsenate-tolerant bacterium isolated from a hot spring in India. Arch Microbiol 195:1-8

Bradford MM (1976) A rapid and sensitive method for the quantitation of microgram quantities of protein utilizing the principle of protein-dye binding. Anal Biochem 72:248-254

Chun J, Lee JH, Jung Y, Kim M, Kim S, Kim BK, Lim YW (2007) EzTaxon: a web-based tool for the identification of prokaryotes based on 16S ribosomal RNA gene sequences. Int J Syst Evol Microbiol 57:2259-2261

Dicks LMT, Van Vuuren HJJ, Dellaglio F (1990) Taxonomy of Leuconostoc species, particularly Leuconostoc oenos, as revealed by numerical analysis of total soluble cell protein patterns, DNA base compositions, and DNA-DNA hybridization. Int J Syst Bacteriol 40:83-91

Garrity GM, Bell JA, Lilburn TG (2003) Taxonomic outline of the procaryotes. Bergey's manual of systematic bacteriology, 2nd edn. Release 4:1-397

Huss VAR, Festl H, Schleifer KH (1983) Studies on the spectrophotometric determination of DNA hybridization from renaturation rates. Syst Appl Microbiol 4:184-192

Jahnke KD (1992) BASIC computer program for evaluation of spectroscopic DNA renaturation data from GILFORD SYSTEM 2600 spectrophotometer on a PC/XT/AT type personal computer. J Microbiol Meth 15:61-73

Kublanov IV, Prokofeva MI, Kostrikina NA, Kolganova TV, Tourova TP, Wiegel J, Bonch-Osmolovskaya EA (2007) Thermoanaerobacterium aciditolerans sp. nov., a moderate thermoacidophile from a Kamchatka hot spring. Int J Syst Evol Microbiol 57:260-264

Laemmli UK (1970) Cleavage of structure proteins during the assembly of the head of bacteriophage T4. Nature (London) 227:680-685

Lee YE, Jain MK, Lee C, Lowe SE, Zeikus JG (1993) Taxonomic distinction of saccharolytic thermophilic anaerobes: description of Thermoanaerobacterium xylanolyticum gen. nov., sp. nov., and Thermoanaerobacterium saccharolyticum gen. nov., sp. nov.; reclassification of Thermoanaerobium brockii, Clostridium thermosulfurogenes, and Clostridium thermohydrosulfuricum E100-69 as Thermoanaerobacter brockii comb. nov., Thermoanaerobacterium thermosulfurigenes comb. nov., and Thermoanaerobacter thermohydrosulfuricus comb. nov., respectively; and transfer of Clostridium thermohydrosulfuricum 39E to Thermoanaerobacter ethanolicus. Int J Syst Bacteriol 43:41-51

Lee YJ, Prange A, Lichtenberg H, Rohde M, Dashti M, Wiegel J (2007) In situ analysis of sulfur species in sulfur globules produced from thiosulfate by Thermoanaerobacter sulfurigignens and Thermoanaerobacterium thermosulfurigenes. J Bacteriol 189:7525-7529

Ley JD, Cattoir H, Reynaerts A (1970) The quantitative measurement of DNA hybridization from renaturation rates. Eur $\mathrm{J}$ Biochem 12:133-142

Liu SY, Rainey FA, Morgan HW, Mayer F, Wiegel J (1996) Thermoanaerobacterium aotearoense sp. nov., a slightly acidophilic, anaerobic thermophile isolated from various hot springs in New Zealand, and emendation of the genus Thermoanaerobacterium. Int J Syst Bacteriol 46:388-396

Ljungdahl LG, Wiegel J (1986) Working with anaerobic bacteria. In manual of industrial microbiology and miotechnology, Washington, pp 84-96

Mesbah M, Premachandran U, Whitman WB (1989) Precise measurement of the $\mathrm{G}+\mathrm{C}$ content of deoxyribonucleic acid by high-performance liquid chromatography. Int J Syst Bacteriol 39:159-167

Murray MG, Thompson WF (1980) Rapid isolation of high molecular weight plant DNA. Nucleic Acids Res 8:4321-4326

Patel MA, Ou MS, Harbrucker R, Aldrich HC, Buszko ML, Ingram LO, Shanmugam KT (2006) Isolation and characterization of acid-tolerant, thermophilic bacteria for effective fermentation of biomassderived sugars to lactic acid. Appl Environ Microbiol 72:3228-3235

Ren NQ, Cao GL, Wang AJ, Lee DJ, Guo WQ, Zhu YH (2008) Dark fermentation of xylose and glucose mix using isolated Thermoanaerobacterium thermosaccharolyticum W16. Int J Hydrogen Energ 33:6124-6132

Rivas R, García-Fraile P, Mateos PF, Martinez-Molina E, Velázquez E (2009) Phylogenetic diversity of fast-growing bacteria isolated from superficial water of lake martel, a saline subterranean lake in mallorca island (Spain) formed by filtration from the mediterranean sea through underground rocks. Adv Stud Biol 1:333-344

Romano I, Dipasquale L, Orlando P, Lama L, d'Ippolito G, Pascual J, Gambacorta A (2010) Thermoanaerobacterium thermostercus sp. nov., a new anaerobic thermophilic hydrogen-producing bacterium from buffalo-dung. Extremophiles 14:233-240

Shaw AJ, Podkaminer KK, Desai SG, Bardsley JS, Rogers Stephen R, Thorne PG, Hogsett DA, Lynd LR (2008) Metabolic engineering of a thermophilic bacterium to produce ethanol at high yield. PNAS 105:13769-13774

Tamura K, Peterson D, Peterson N, Stecher G, Nei M, Kumar S (2011) MEGA5: molecular evolutionary genetics analysis using maximum likelihood, evolutionary distance, and maximum parsimony methods. Mol Bio Evol 28:2731-2739

Thompson JD, Gibson TJ, Plewniak F, Jeanmougin F, Higgins DG (1997) The CLUSTAL_X windows interface: flexible strategies for multiple sequence alignment aided by quality analysis tools. Nucleic Acids Res 25:4876-4882

Xue YF, Xu Y, Liu Y, Ma YH, Zhou PJ (2001) Thermoanaerobacter tengcongensis sp. nov., a novel anaerobic, saccharolytic, thermophilic bacterium isolated from a hot spring in Tengcong, China. Int J Syst Evol Microbiol 51:1335-1341

Yuan LJ, Zhang YQ, Guan Y, Wei YZ, Li QP, Yu LY, Li WJ, Zhang YQ (2008) Saccharopolyspora antimicrobica sp. nov., an actinomycete from soil. Int J Syst Bacteriol 58:1180-1185 